Dinamika Sosial Budaya, Vol 21, No. 2, Desember 2019, pp 172-181

p-ISSN: 1410-9859\& e-ISSN: 2580-8524

http://journals.usm.ac.id/index.php/jdsb

\title{
STRATEGI PENGENTASAN KEMISKINAN MELALUI PROGRAM PENDIRIAN DAN PENGEMBANGAN KOPERASI
}

\author{
Endang Rusdianti \\ Fakultas Ekonomi Universitas Semarang \\ endang_rusdianti@yahoo.com \\ Sri Purwantini \\ Fakultas Ekonomi Universitas Semarang \\ ipungdosenusm@usm.ac.id \\ Nirsetyo Wahdi \\ Fakultas Ekonomi Universitas Semarang \\ nswahdi.feusm@gmail.com
}

\begin{abstract}
The results of the first year of research show that there has been a group of business activities called UPPKS (Usaha Peningkatan Pendapatan Keluarga Sejahtera) but the results are less than optimal because there are still many obstacles and weaknesses in managing management and business activities. The existing activities turned out to be still individual, not in groups. The research objective is the development of sustainable business activity groups in the form of cooperative embryos related to efforts to increase the role of women for poverty alleviation.

This research uses a qualitative method which is a description of conditions in the field. The solution implemented is through training and assistance in establishing cooperatives.

The results obtained are increased motivation to develop business through group activities, namely cooperatives, this is evident from the willingness to establish cooperatives even though they are not in the form of legal entities (embryos). Training and assistance are needed for the continuity of the cooperative.
\end{abstract}

Keywords: motivation, cooperative, sustainable

\section{Pendahuluan}

Wanita golongan ekonomi lemah, yang berpenghasilan rendah perlu adanya peningkatan kemampuan dan ketrampilan melalui kegiatankegiatan ekonomi produktif. Tujuannya adalah memperluas kesempatan kerja dan menciptakan usaha bagi diri sendiri. Fenomena yang ada menunjukkan bahwa telah ada kelompok kegiatan usaha dibawah binaan Dinas Pemberdayaan Perempuan dan Keluarga Berencana yang disebut UPPKS (Usaha Peningkatan Pendapatan Keluarga Sejahtera) hanya saja hasilnya kurang maksimal. Selain itu masih banyak kendala dan kelemahan didalam pengelolaan manajemen dan kegiatan usaha yang ternayata masih bersifat individual, belum secara kelompok. Perempuan memang memiliki potensi untuk menopang kehidupan keluarga, namun perempuan tidak bisa mengklaim bahwa dia adalah penyangga utama kehidupan rumah tangga (Lestari dkk, 1997). Pada perempuan pedagang tradisional di Semarang cenderung tidak mau menonjolkan diri, melainkan hanya mendukung suami dalam memenuhi pendapatan keluarga (Wibowo, 2002).
Di Kabupaten Semarang banyak industri sandang yang menyerap banyak tenaga kerja dan menurut Yuniarti dan Haryanto (2005), pendapatan perempuan yang bekerja di sector industry sandang, memberikan kontibusi yang nyata pada peningkatan pendapatan keluarga. Masalahnya di Kecamatan Ungaran Timur, ibuibu banyak yang tidak bekerja sedangkan penghasilan suami hanya cukup untuk memenuhi kebutuhan sehari-hari. Kelompok usaha yang ada, hanyalah sekedar pekerjaan yang sifatnya sambilan dan merupakan ajang silahturahmi dari ibu-ibu. Motivasi untuk mengembangkan usaha hanya ada dari beberapa ibu saja karena terbentur oleh masalah permodalan, perkembangan teknologi dan ketrampilan serta kemampuan yang rendah. Hal ini sesuai dengan hasil penelitian Hastuti dan Dyah Respati (2008), yang menyatakan bahwa perempuan miskin kurang mendapat prioritas peningkatan kualitas sumber daya manusia, pendidikan dan pendapatan relative rendah, kurang memiliki kesempatan akses kontrol terhadap sumberdaya. Diperlukan model 
pemberdayaan perempuan miskin dengan memperhatikan keterlibatan perempuan agar secara aktif mampu berpartisipasi dalam pemanfaatan sumberdaya perdesaan dengan penguatan perempuan miskin merupakan inti pemberdayaan perempuan diberi kesempatan setara dengan laki-laki dalam pemanfaatan sumberdaya di perdesaan. Akses pendidikan juga rendah, banyak anak-anak lulusan SM P yang tidak melanjutkan studi ke jenjang yang lebih tinggi (Endang, R,dkk,2013). Menurut Paulus,W, dkk, 2014, fenomena yang ada dari kondisi kemiskinan masyarakat menunjukkan masih banyaknya perempuan yang tidak bekerja dan kurang maksimalnya program UUPKS di Kabupaten Semarang. Dalam proses tersebut pengintegrasian wanita dalam pembangunan, terutama wanita dari golongan ekonomi lemah, yang berpenghasilan rendah perlu di tingkatkan, melalui peningkatan kemampuan dan ketrampilan untuk melakukan kegiatan-kegiatan ekonomi produktif, dalam rangka memperluas kesempatan kerja dan menciptakan usaha bagi diri sendiri melalui kelembagaan yang berbentuk koperasi serba usaha.

Pemberdayaan perempuan miskin memerlukan adanya penguatan peran aktif yang dilakukan melalui peningkatan pengetahuan, ketrampilan sebagai sarana penguatan ekonomi social (Rahayuningsih, dkk, 2015). Perlu adanya jiwa kewirausahaan dan motivasi untuk berkembang sesuai hasil penelitian Endang R, dkk, 2018, bahwa pemberdayaan perempuan, kaitannya dengan kemiskinan dipengaruhi oleh jiwa kewirausahaan sosial dan motivasi. Oleh karena itu perlu adanya strategi yang bisa digunakan untuk pengentasan kemiskinan melalui pendirian dan pengembangan koperasi karena koperasi adalah wadah yang bisa digunakan oleh, untuk dan dari anggota. Ada 3 pilar dalam pembangunan yang disebut sebagai trilogi pembangunan yaitu pemerataan pembangunan dan hasil-hasilnya menuju terciptanya keadilan sosial bagi seluruh bangsa Indonesia, pertumbuhan ekonomi serta stabilitas nasional yang sehat dan dinamis. Ketiga pilar tersebut mengikat keseluruhan pelaku ekonomi yang ada. Baik koperasi, swasta maupun BUMN (Aleria Irma Hatneny,2017). Koperasi mampu memperkenalkan kesadaran berekonomi, menggerakkan sumber-sumber ekonomi (termasuk sumber daya manusia) yang masih belum atau kurang dimanfaatkan menjadi suatu kekuatan produktif yang menumbuhkan nilai tambah. Koperasi sebagai gerakan ekonomi partisipatif menyatu padukan potensi-potensi kecil yang terpisah-pisahkan menjadi kekuatan bersama yang lebih besar. Koperasi merupakan wadah usaha partisipatif dan semangat kerjasama serta silahturahmi, maka peranan koperasi sesuai dengan tugas-tugas yang menyangkut stabilitas sosial. Selain itu penelitian menunjukkan bahwa permodalan, manajemen organisasi dan peran birokrasi mempengaruhi keberhasilan koperasi (Ari Susanti, 2018).

\section{Kajian Literatur}

\section{Analisis Lingkungan Bisnis}

Analisis SWOT menurut Rangkuty, F, (2005), adalah identifikasi berbagai faktor secara sistematis untuk merumuskan strategi perusahaan. Analisis ini didasarkan pada logika yang dapat memaksimalkan kekuatan (Strength) dan peluang (Opportunities), namun secara bersamaan dapat meminimalkan kelemahan (Weaknesses) dan ancaman (Threats). Proses pengambilan keputusan strategis selalu berkaitan dengan pengembangan misi, tujuan strategi, dan kebijakan organisasi. Dengan demikian perencana strategis harus menganalisis faktor-faktor strategis perusahaan dalam kondisi yang ada saat ini. Hal ini sering disebut dengan analisis situasi atau kondisi.

\section{Pemberdayaan Masyarakat}

Pemberdayaan masyarakat merupakan upaya untuk meningkatkan harkat dan martabat lapisan masyarakat yang dalam kondisi sekarang tidak mampu untuk melepaskan diri dari perangkap kemiskinan dan keterbelakangan. Dengan kata lain, pemberdayaan adalah memampukan dan memandirikan masyarakat. Pemberdayaan masyarakat juga dapat diwujudkan dengan menerapkan prinsip-prinsip dasar pendampingan masyarakat, yaitu (Karsidi, 2002): (1) Belajar dari masyarakat; (2) Pendamping sebagai fasilitator, masyarakat sebagai pelaku; (3) Saling belajar, saling berbagi pengalaman.

Pemberdayaan UKM banyak menghadapi permasalahan yaitu kesulitan terhadap permodalan, tehnologi, rendahnya kualitas sumber daya manusia, mahalnya harga bahan baku dan banyaknya pesaing yang bergerak dalam bisnis yang sama. Untuk meningkatkan pendapatan masyarakat yang bergerak dalam usaha skala mikro pada sektor informal, ditempuh langkah pemberdayaan usaha mikro sebagai berikut: (1) Pengembangan usaha mikro, termasuk yang tradisional; (2) Penyediaan skim pembiayaan dan 
peningkatan kualitas layanan lembaga keuangan mikro; (3) Penyediaan insentif dan pembinaan usaha mikro; serta (4) Peningkatan kualitas koperasi untuk berkembang secara sehat sesuai dengan jati dirinya dan membangun efisiensi kolektif bagi pengusaha mikro dan kecil.

Pemberdayaan Masyarakat. adalah bagian dari paradigma pembangunan yang memfokuskan perhatiannya kepada semua aspek yang prinsipil dari manusia di lingkungannya yakni mulai dari aspek intelektual (Sumber Daya Manusia), aspek material dan fisik, sampai kepada aspek manajerial (Rahayu, 2008).

\section{Pengentasan kemiskinan}

Pengentasan kemiskinan merupakan masalah pembangunan yang sangat kompleks dan mempunyai dimensi tantangan lokal, nasional maupun global. Oleh karena itu, program bantuan seharusnya difokuskan untuk menumbuhkan ekonomi produktif, dengan memberikan bantuan modal usaha tanpa anggunan pada masyarakat miskin, juga memberikan pelatihan keterampilan untukmenumbuhkan jiwa wirausaha kemandirian.Dengan demikian, secara bertahap, masyarakat membebaskan diri dari ketergantungan kepada pemerintah (Atma Ras,2013)

Masalah kemiskinan tidak dapat dipisahkan dari faktor penyebabnya. Faktor penyebab kemiskinan terbagi dua aspek, yaitu aspek internal maupun eksternal Dalam pengentasan kemiskinan ini diperlukan juga motivasi dan etos kerja personal untuk berusaha agar terlepas dari kemiskinan. Sebagus apapun program dan berapapun besarnya anggaran yang dikeluarkan untuk pengentasan kemiskinan, kalau manusianya enggan atau tidak memiliki kemauan untuk lepas dari kemiskinan maka tidak akan pernah lepas dari kemiskinan

Pengentasan kemiskinan juga membutuhkan sinergitas peran antara pemerintah, dan masyarakat. Pengentasan kemiskinan tidak dapat dilakukan hanya dengan ego sektoral, tetapi harus komprehenshif dari berbagai unsur yaitu pemerintah, peran lembaga terkait dan masyarakat sendiri sebagai subjek dan objek perubahan.

Strategi pengentasan kemiskinan menurut United Nations Economic and Social Comission for Asia Pacific (UNESCAP) bahwa strategi penanggulangan kemiskinan terdiri dari penanggulangan kemiskinan uang; kemiskinan akses ekonomi, sosial dan budaya; dan penanggulangan kemiskinan terhadap akses kekuasaan dan informasi (Yulianto 2005).
Kemiskinan disebabkan oleh sistem yang tidak adil dan tidak merata dalam memberikan kesempatan dan akses bagi setiap masyarakat untuk memenuhi kebutuhannya. Upaya pengentasan kemiskinan tersebut dapat menggunakan instrumen lembaga yang bernama koperasi.

\section{Koperasi}

Koperasi merupakan suatu wadah yang menjadi sarana kepentingan pribadi dan kepentingan kelompok. Sehingga melalui kegiatan kelompok tersebut, kepentingan pribadi para anggota menjadi kekuatan pendorong yang memberikan manfaat bagi seluruh anggota kelompok tersebut (Sartika, 2002). Koperasi adalah badan usaha yang beranggotaan orang seorang atau badan usaha yang bertujuan untuk meningkatkan kesejahteraan anggotanya. menjaga kerukunan antar sesama dan bekerja untuk kepentingan bersama. Koperasi lebih menekankan pada paham kooperativisme (coorperation based) yang akan membentuk kekuatan yang berlipat ganda, bersinergi dalam rangka mencapai efisiensi (Sri Edi Swasono, 2012). Kelebihan koperasi dibanding bentuk perusahaan yang lain adalah koperasi sebagai kumpulan modal sosial tidak mengejar keuntungan tetapi untuk melayani anggotanya

\section{Metode Penelitian}

Penelitian ini menggunakan pendekatan kualitatif (Neuman, 2007; Creswell, 2009) yang bersifat deksriptif. Penelitian kualitatif merupakan eksplorasi dan pemaknaan atas permasalahan atau fenomena sosial. Metode penelitian yang digunakan adalah eksplorasi literatur dengan data yang diperoleh dari buku dan jurnal yang berkaitan dengan teori. Metode exploration yaitu suatu penelitian yang berusaha mendapatkan faktor-faktor yang menunjukkan kondisi internal terkait dengan kekuatan dan kelemahan serta faktor eksternal terkait dengan ancaman serta peluang yang ada. Kemudian kaitannya dengan pengentasan kemiskinan dilakukan program pelatihan oleh mitra terkait dengan pemahaman mengenai koperasi, manajemen/ pengelolaan/ kelembagaan koperasi/ pembukuan koperasi sebagai alternatif penyelesaian masalah pengentasan kemiskinan dengan menggunakan alternatif pendirian koperasi yang dalam kondisi saat ini masih berupa embrio koperasi(terutama koperasi simpan pinjam)

Metode penarikan informan yang digunakan adalah purposive sampling dengan 
Dinamika Sosial Budaya, Vol 21, No. 2, Desember 2019, pp 172-181

p-ISSN: 1410-9859\& e-ISSN: 2580-8524

http://journals.usm.ac.id/index.php/jdsb

kriteria (1) perempuan anggota UPPKS (2) memiliki usaha. Teknik pengumpulan data dilakukan dengan wawancara, observasi/ pengamatan dan dokumentasi. Validitas data menggunakan teknik trianggulasi yaitu anggota UPPKS/ PLKB/ pemerintah.Teknik pengumpulan data dilakukan dengan wawancara, observasi/ pengamatan dan dokumentasi.

\section{Hasil penelitian dan pembahasan}

Program Usaha Peningkatan Pendapatan Keluarga Sejahtera (UPPKS) merupakan salah satu upaya untuk Meningkatkan Kesejahteraan Dan Ketahanan Keluarga. Pelaksanaan UPPKS membutuhkan keterlibatan semua pihak untuk mewujudkan kehidupan masyarakat yang mandiri dan berkualitas. Beberapa faktor yang meningkatkan partisipasi masyarakat dalam UPPKS adalah mudahnya akses Informasi, mengakses pasar, akumulasi pendanaan dan modal, mitra usaha, kesempatan pengelolaan usaha, kesempatan berusaha, berorganisasi serta pembinaan dari berbagai pihak yang bisa menumbuhkan semangat kebersamaan dan kewirausahaan. Faktor yang menghambat partisipasi masyarakat kurang efektif dalam UPPKS yaitu keterbatasan modal usaha, rendahnya penguasaan teknologi canggih, tingkat pendidikan rendah, kurang bisa menganalisis pasar dan jumlah produksi yang kecil. Tujuan dibentuknya UPPKS adalah untuk mempermudah melakukan kegiatan usaha ekonomi produktif, disamping itu juga akan mempermudah berbagai pihak untuk melakukan pembinaan terhadap usaha ataupun pengembangan tenaga kerja terampil dan inovatif sehingga usaha yang dikembangkan berdaya saing. Dengan adanya UPPKS diharapkan pendapatan keluarga dapat meningkat yang kemudian akan memperbaiki kesejahteraan, baik dari keluarga peserta KB yang bersangkutan maupun dari seluruh anggota kelompoknya. Struktur umur dan tingkat pendidikan peserta perempuan UPPKS antara $25 \mathrm{~s} / \mathrm{d} 49$ tahun dan terbanyak berpendidikan SMP.

Pembentukan kelompok menyepakati untuk bisa saling berkomunikasi melalui pertemuan rutin yang kegiatannya adalah memecahkan masalah yang ada pada kelompok, menggali potensi sumberdaya manusia dan sumber daya alam yang berdasarkan kondisi sosial budaya dan ekonomi anggota kelompok, memberikan pemahaman tentang pentingnya kelembagaan UPPKS dan sebagai penghubung antara kelompok dengan pemerintah.
Berbagai strategi digunakan para pengusaha UPPKS untuk meningkatkan pemasaran produknya, dari mulai menciptakan produk yang dibutuhkan konsumen, memberikan harga yang sesuai dengan target pasar, memilih lokasi usaha yang strategis, serta melakukan kegiatan promosi yang mendukung peningkatan penjualan. Menghasilkan produk yang memiliki keunggulan dalam hal bentuknya yang unik, lebih enak rasanya, lebih murah harganya sudah berlabel dan lebih higienis. Dengan bantuan tersebut anggota UPPKS dapat menghasilkan berbagai macam produk makanan olahan, souvenir, kerajinan, konveksi ataupun produk hasil pertanian ataupun usaha jasa salon, warungan, laundry yang mereka kerjakan. Di masing-masing kelompok memiliki keunggulan produk yang berbeda sehingga dapat menjadikan kelompok UPPKS mempunyai ciri khas tersendiri.

Anggota kelompok bisa menjalankan bergabung membentuk kelompok usaha bersama yang kecil atau yang disebut sub usaha kelompok. Dalam semua bentuk kegiatan ekonomi produktif dari anggota kelompok UPPKS, baik perorangan atau bersama, ikatan dalam kelompok dan tanggungjawab bersama tetap ada. Ikatan dalam kelompok dapat dimanfaatkan untuk kegiatan ekonomi produktif, tidak hanya karena berdasarkan alasan bahwa pinjaman dari sumber penyandang dana hanya disalurkan melalui kelompok, tetapi juga dalam bidang pembelian bahan baku atau pemasaran produk. Kelompok juga bisa memberi bimbingan teknis maupun administrasi kepada anggota yang mempunyai usaha. Oleh karena alternatif penyelesaian permasalahan adalah dengan pendirian koperasi, dalam hal ini koperasi simpan pinjam maka usaha pembinaan dilakukan selain yang sudah dilaksanakan oleh Pemerintah juga dilakukan oleh Perguruan Tinggi. Untuk pelatihan dan pembinaan mengenai koperasi dilakukan kerjasama dengan mitra yaitu PPKU (Pusat Pengembangan Koperasi dan UKM ) Universitas Semarang

Kemandirian anggota dalam kelompok sangatlah diharapkan bisa tercapai Namun demikian, beberapa lembaga seperti BKKBN dapat memfasilitasi akses untuk mendapat bantuan modal usaha yang bersumber dari berbagai pihak antara lain: a. APBN/APBD II $\mathrm{f}$. PNPM b. Perbankan c.PT. PNM d. Koperasi e. Sektor Swasta/CSR. f.Disperindag. Untuk bisa memperoleh bantuan modal usaha, kelompok UPPKS harus terdaftar dalam databasis kelompok UPPKS. Agar dana dimanfaatkan secara bertanggung jawab, maka bantuan/kredit modal 
Dinamika Sosial Budaya, Vol 21, No. 2, Desember 2019, pp 172-181

p-ISSN: 1410-9859\& e-ISSN: 2580-8524

http://journals.usm.ac.id/index.php/jdsb

diupayakan ke kelompok UPPKS penerima bantuan atau kredit yang benar-benar mempunyai kegiatan usaha ekonomi produktif dan dikelola dengan baik. Alternatif lain untuk penyelesaian permasalahan adalah pendirian koperasi simpan pinjam

Yang menjadi informan untuk penelitian ini adalah 24 orang yang tergabung dalam kegiatan AKU (Andalan Kelompok UPPKS) di Kecamatan Ungaran Timur. Jumlah anggota AKU dibawah bmbingan PLKB Kecamatan dan mereka mewakili kelompok yang ada di 10 Kelurahan/Desa , masing2 anggta AKU Kecamatan ini mewakili lebih dari satu kelompok usaha yang ada di kelurahan/desa. Tujuan dari kelompok AKU adalah sebagai wadah untuk menampung aspirasi dari masing2 kelompok UPPKS yang ada di desa/kelurahan, Petugas sebagai kepanjangan tangan dari Pemerintah dalam hal ini Dinas BKKBN dimana bentuk pembinaannya meliputi a) bantuan permodalan dalam bentuk hibah antara $\mathrm{Rp} 5$ - 7 juta , b) melakukan penjualan/pemasaran dengan cara melibatkan dalam event-event yang diselenggarakan oleh Pemerintah dan lain-lain , c) pelatihan dari dinas terkait sesuai dengan usulan kelompok ataupun program,d) bantuan peralatan penunjang usaha, e) pelatihan dari perguruan tinggi, swasta. Pilihan lokasi untuk pembinaan lebih lanjut dari pengembangan usaha melalui koperasi ini adalah di Kecamatan Ungaran Timur dengan pertimbangan hasil penelitian tahap pertama menunjukkan bahwa :

a. Hasil penelitian tahap pertama menunjukkan bahwa kelompok ini yang berperan aktif dalam kegiatan usaha

b. Anggotanya mempunyai motivasi untuk berkembang

c. Anggotanya memiliki usaha yang cukup baik tetapi masih memerlukan pembinaan terutama dari sisi permodalan meskipun dari sisi pemasaran juga sebenarnya memerlukan pembinaan

d. Usaha yang dilakukan banyak merekrut masayarakat setempat sebagai tenaga kerja . jadi paling tidak berpotensi untuk membantu masyarakat dalam usaha pengentasan kemiskinan.

Penduduk Kecamatan Ungaran Timur yang tergabung dalam kelompok Usaha AKU adalah kaum perempuan yang umumnya mempunyai ciri yang sama yaitu kurang berpendidikan. Dari 28 anggota yang ada ternyata hanya aktif sebanyak 24 orang dan jumlah inilah yang kemudian diteliti. Kelompok ini terdiri dari perempuan yang lebih berperan sebagai ibu rumah tangga dengan usahanya yang digeluti bersifat sampingan seperti usaha jasa, membuat makanan kecil, menjahit, membuat jamu, usaha sprei Dari sisi pendidikan maka $35 \%$ berpendidikan SD, $25 \%$ berpendidikan SMP dan sisanya berpendidikan SMA . Kelompok AKU merupakan kelompok usaha yang anggotanya tersebar di seluruh kecamatan Ungaran Timur dimana umumnya yang terbanyak bergerak dalam bidang usaha kuliner, pedagang kelontong, jasa, penjahit, bidang pertanian dan peternakan dan industri jamu tradisional. Kelompok ini setiap bulannya rutin mengadakan pertemuan dibawah bimbingan PLKB Kecamatan untuk membahas berbagai hal yang berhubungan dengan bidang usahanya maupun keluarga ( terkait dengan program Keluarga Berencana). Pada pertemuan tersebut adakalanya dilakukan pembinaan dari dinas terkait maupun dari Perguruan Tinggi ataupun pelaku usaha yang sukses untuk memberikan motivasi agar usahanya menjadi lebih sukses.

Hasil wawancara dengan ibu-ibu anggota kelompok AKU menunjukkan bahwa ada beberapa kekuatan, kelemahan, ancaman dan peluang dari usaha yang dilakukan dalam kehidupannya untuk membantu perekonian keluarga. Sisi kekuatannya adalah bahwa kelompok usaha ini adalah terdiri dari ibu-ibu yang mempunyai motivasi yang sama yaitu berkemauan untuk menambah pendapatan keluarga, niat untuk saling bersilahturahmi, tidak ada perasaan saling bersaing, produknya bervariasi, produknya memiliki citarasa yang menurut pembeli berbeda, memiliki pelanggan yang sudah pasti, proses pengerjaan yang bagus dan dengan penetapan harga yang terjangkau, berkemampuan untuk menerima pesanan, biaya produksinya murah, tenaga kerja murah karena memanfaatkan anak-anak untuk proses. Sisi kelemahannya adalah terbatasnya jangkauan pemasaran, proses produksi yang masih mengandalkan proses manual, mengandalkan promosi yang sifatnya word of mouth, distribusi barangnya tidak luas, permodalan terbatas, kurang trampil sehingga model dan bentuk produk tidak berkembang, pengenalan produk keluar daerahnya berdasarkan event-even yang diselenggarakan oleh pemerintah dan sifatnya menunggu undangan dari pemerintah, produk tidak berlabel, kemasannya sederhana, teknologinya belum canggih. Sisi Ancaman adalah curangnya pembeli yang membeli barang dengan memberi label yang seakan-akan produk tersebut adalah hasil produksinya, bahan baku yang sulit didapatkan 
didaerah lokal, munculnya produk yang sama di kelompok lain dengan variasi dan tampilan yang berbeda,modal kurang mencukupi, adanya pesaing yang menggunakan tehnologi yang lebih canggih. Sisi Peluang adalah masih adanya campur tangan pemerintah untuk melibatkan mereka dalam even tertentu, penggemar makanan atau pembeli tetapnya sudah ada, tidak ada perasaan bersaing karena umumnya masih ada hubungan kekeluargaan, dukungan masyarakat terhadap kegiatan usaha, budaya masyarakat yang cukup baik.

Berdasarkan kondisi internal dan eksternal sebagai hasil wawancara dengan para informan tersebut maka dapat diperoleh data adanya beberapa kendala yang terkait dengan usaha mereka mengembangkan usahanya sebagai usaha sampingan yang bisa membuahkan hasil pendapatan untuk tujuan meringankan beban keluarga dan membantu pihak suami. Berikut ini hasil wawancara dengan para informan : "Walaupun kami sebenarnya adalah ibu rumah tangga tetapi dalam kenyatannya tidak sekedar mengurus rumah tangga, tetapi kami harus ikut memikirkan keadaan ekonomi keluarga bagaimana agar cukup dan dari hasil setiap saat ada pertemuan yang difasilitasi oleh BKKBN, muncul motivasi kami untuk melakukan usaha yang bukan merupakan tujuan pokok tetapi hanya sambilan sambil mengembangkan hobby berdasarkan kemampuan yang ada. Tujuan utama yaitu memanfaatkan waktu luang, menyalurkan hobby, kalau bisa ya dijual untuk menambah penghasilan sehingga bisa menutup kebutuhan keluarga atau mengurangi beban suami“

Adapun kendala yang ada didalam kegiatan tersebut adalah :

\section{a. Dari sisi aspek proses produksi}

Pelaku usaha umumnya masih menggunakan proses produksi yang sifatnya tradisional, sehingga kualitas hasil produksinya kurang memuaskan ( baik dari sisi rasa, bentuk ataupun tampilannya). Hal ini sering tidak disadari oleh pelaku usaha tersebut, sehingga dalam jangka panjang sulit untuk berkembang khususnya dengan adanya pesaing yang sudah menggunakan alat teknologi yang lebih canggih. Ketika dilakukan wawancara dengan informan, mereka menuturkan bahwa memang proses produksinya masih tradisional atau kebanyakan sifat pengerjaannya adalah manual sehingga kadang-kadang bentuk dari makanan yang dibuat tidak sama dan tidak bagus. Tetapi hal ini dirasakan merupakan hal yang biasa bagi mereka karena toh ada yang mau membeli." Informan juga tidak mempersalahakan kehadiran pesaing yang menggunakan teknologi yang lebih canggih karena dengan pertimbangan teknologi baru berarti butuh biaya untuk membeli karena selain tidak ada modal juga kesulitan penggunaannya.

b. Kemasan produk

Pelaku usaha umumnya masih menggunakan kemasan yang masih sederhana dengan tanpa memperhatikan aspek seni tampilan dan usaha untuk meyakinkan pembeli tentang produk baik dari sisi ke halal an, kadaluwarsanya produk dan kesehatan. Selain itu dari sisi kemasan produk ini juga masih ada kendala yaitu belum menggunakan merk dan labelnya biasanya dalam bentuk stiker yang hal ini banyak mengandung kelemahan yaitu diganti oleh pembeli untuk dijual dengan merk pembeli yang seakan-akan adalah hasil produk mereka. Wawancara dengan informan menunjukkan bahwa " mereka biasa menjual dengan kemasan kosong dan berdasrkan kepercayaan terhadap pembeli mereka meyakini bahwa ada kejujuran dari pembeli dan pembeli tidak akan melakukan kecurangan. Informan juga menjelaskan bahwa dengan model penjualan seperti ini mereka tetap mempunyai langganan pembeli yang langgeng ".

\section{c. Pemasaran}

Dalam memasarkan produknya masih sangat terbatas dilingkungan tempat tinggal atau hanya antar desa. Umumnya masih dipasarkan sendiri tanpa melalui perantara..padahal sebetulnya produk yang dihasilkan punya potensi untuk dipasarkan dengan jangkauan yang lebih luas maupun jauh. Pembeli datang berdasarkan model pemasaran yang sifatnya gethok tular, datang sendiri ke tempat produksi dan menjual ke daerah mereka atau dititipkan ke warung-warung yang sudah menjadi langganan mereka. Konsep pemasaran yang berkaitan dengan harga dijalankan dengan sangat sederhana artinya asal bisa menutup biaya produksi dan sedikit keuntungan serta harapan kelangsungan hubungan untuk menjaga silahturahmi itu yang dipentingkan. Dari sisi produk, belum emnunjukkan adanya inovasi yang baru karena beranggapan memeng itulah kreasi mereka yang berbeda dengan yang lain. Dari sisi promosi, mereka menjalankan model gethok tular dan mengutamakan tali silahturahmi serta memanfaatkan event-event yang diselenggarakan oleh pemerintah atau yang lainnya. Dari sisi saluran distribusi, mereka tidak menggunakan 
perantara , karena usahnya hanya dalam skala kecil dan untuk yang skala usaha besar hanya karena menunggu adanya pesanan. Hasil wawancara menunjukkan bahwa " informan lebih mengutamakan kelanggengan hubungan kekeluargaan daripada mencari banyak keuntungan, karena keberlangsungan hubungan akan menjamin keberhasilan usaha dalam jangka panjang, selain itu pertimbangan tidak menggunakan alat promosi yang lain adalah karena faktor modal yang tidak mencukupi “

\section{d. Permodalan}

Umunya pelaku usaha menggunakan modal semdiri yang terbatas jumlahnya. Berdasarkan informasi dari para informan, tidak ada koperasi atau semacam lembaga keuangan yang resmi. Mereka mengandalkan hibah yang diberikan sebesar 5- 7 juta per kelompok dan diharapkan dana ini adalah merupakan dana bergulir, karena sejak tahun 2014 dana ini baru diberikan sekali. Pelaku usaha tidak berani menggunakan jasa rentenir karena bunganya cukup tinggi sehingga kehadiran rentenir bukannya membentu tetapi justru menjerat dan menyusahkan. Mereka sebetulnya ingin mengembangkan usahanya ,tetapi mereka tidak berani mengambil pinjaman dari bank dengan alasan tidak mau mengambil resiko.dengan tidak adanya kemempuan untuk mengembanlikan dalam jumlah yang berl;ipat, dengan bunga dan denda apabila tidak bisa membayar

Dari penjelasan informan tersebut yang terlihat dari kendala di setiap sisi pengelolaan makadapat dikatakan bahwa penyebab utama kendala adalah permodalan usahanya. Manjaemen usaha bisa jalan kalau ada modal untuk mengembangkannya baik dari sisi proses produksi, pemasaran, distribusi dan lain-lain. Oleh karena itulah ditawarkan solusi kepada para pengrajinyang tergabung dalam AKU tersebut dengan mendirikan koperasi. Pendirian koperasi masih merupakan harapan untuk penyelesaian masalah tetapi sebelum berbentuk badan hukum dan masih pendirian awal maka disebut sebagai embrio koperasi atau bisa juga disebut KUB (kelompok Usaha Bersama) . Pendirian koperasi sebagai salah satu alternatif solusi mengenai permodalan ini dengan mempertimbangkan bahwa usaha mereka adalah usaha rumahan dengan modal yang tidak besar, dan faktor silahturahmi sangat dipertahankan sehingga kalau seperti ini maka prinsip koperasi yaitu sebagai ekonomi kerakyatan yang dimiliki dan kembali kepada anggota. Hal ini didukung adanya informasi dari informan bahwa "sementara saat ini masyarakat mempunyai cara sendiri untuk mengatasi kemiskinannya dengan cara: berhutang pada berbagai sumber pinjaman informal, bekerja serabutan, isteri dan anak bekerja, memanfaatkan sumber daya alam di sekelilingnya, bekerja di luar daerah dan berhemat melalui mengurangi atau mengganti jenis makanan serta mengatur keuangan ".Upaya pengentasan kemiskinan tersebut dapat menggunakan instrumen lembaga yang bernama koperasi. Alternatif penyelesaian permasalahan permodalan biasanya akan lebih mudah apabila diselesaikan dengan cara simpan pinjam dan karena koperasi sebagai wadah berarti pendirian koperasi simpan pinjam bisa menjadi alternatif pendanaan.

Sebenarnya koperasi ini bisa menjadi pengembangan dari usaha kelompok AKU yang bergerak dalam usaha simpan pinjam skala kecil, yang kemudian bisa dikembangkan kearah bentuk embrio koperasi yang lebih menjanjikan untuk memenuhi kebuhan akan tambahan modal usahanya. Kesesuaian koperasi sebagai bentuk ekonomi dalam keadaan ekonomi sosial masyarakat karena koperasi dibangun di atas semangat kolektivisme atau kebersamaan yang tinggi dengan berlandaskan azas kekeluargaan. Koperasi menyadarkan kepentingan bersama, menolong diri sendiri secara bersama dalam meningkatkan kesejahteraan dan kemampuan produktif.

Informan menyatakan bahwa mereka antusias saat dijelaskan tentang manfaat adanya koperasi dikalangan anggota kelompok usaha. Salah satu anggota kelompok mengatakan “ Sebetulnya kami ingin mengembangkan simpan pinjam di kelompok kami, tetapi kami tidak tahu bagaimana caranya, Dan umumnya masalah kedisiplinan untuk menjalankan kewajibannya masih menjadi kendala karena lokasi anggota yang terpencar jauh di luar desa. ".

Tahap berikutnya yang dilaksanakan adalah membantu para pengelola kelompok usaha AKU ini dalam pendirian koperasi yaitu dengan cara membentuk pengurusnya dan mulai dengan mengumpulkan permodalan sebagai stimulus diberikan bantuan untuk menutup simpanan pokok dan menentukan secara musyawarah untuk besarnya simpanan wajibnya. Yang terpenting sekali lagi bahwa koperasi harus lebih diperkuat lagi peran dan fungsinya. Juga semua masyarakat mau menjadi anggota dari koperasi. Sehingga pengentasan kemiskinan setidaknya dapat dilakukan dengan optimal. Kegiatan pendampingan dengan memberikan pelatihan 
mengenai kejelasan tentang pengoperasian wadah koperasi yang dimulai dari kegiatan pelatihan tentang pentingnya koperasi dan macam koperasi serta sturktur organisasi yang ada dalam koperasi Kegiatan berikutnya adalah melakukan kerjasama dengan Dinas Koperasi setempat untuk mendapatkan pembinaan

Masalah intern yang masih perlu perbaikan mencakup masalah keanggotaan, kepengurusan, pengawas, manajer, dan karyawan koperasi. Sedangkan masalah ekstern mencakup hubungan koperasi dengan bank, dengan usaha-usaha lain, dan juga dengan instansi pemerintah. (hasl wawancara dengan informan.) Ditinjau dari segi kualitas masalah keaggotaan koperasi tercermin dari tingkat pendidikan mereka yang pada umumnya masih rendah. Ketrampilan dan keahlian yang dimiliki oleh para anggota terbatas, Kebanyakan anggota belum menyadari bahwa koperasi bisa menjadi suatu wadah usaha yang dimaksudkan untuk meningkatkan kegiatan ekonomi dan kesejahteraan mereka. Sebaiknya dalam kelompok tersebut harus ada tokoh yang berfungsi sebagai penggerak organisatoris untuk menggerakkan koperasi kearah sasaran yang benar. Partisipasi mereka dalam kegiatan organisasi juga masih harus ditingkatkan. Pengurus harus jujur dan bisa membagi tugas sesuai dengan fungsinya dan bisa berkoordinasi dengan anggota, punya dedikasi yang tinggi. Kepercayaan anggota terhadap pengurus adalah penting.Selain itu hubungan baik dengan pemerintah perlu ditingkatkan agar fasilitas mengalir ke koperasi. Untuk keperluan pengembangan, koperasi perlu adanya pembinaan dan pendidikan yang lebih intensif untuk tugastugas operasional. Dalam melaksanakan tugas tersebut, apabila belum mempunyai tenaga profesional yang tetap, dapat dilakukan dengan bekerja sama dengan lembaga-lembaga pendidikan yang terkait. Peran koperasi dapat dirasakan oleh pengrajin , seperti yang dikemukakan oleh salah satu anggota yang di wilayahnya sudah ada koperasi, meyatakan bahwa "Kami sangat senang dengan adanya koperasi ini, kami bisa pinjam modal untuk buka usaha, tanpa ada koperasi kami hanya memiliki modal sedikit, itu tidak cukup untuk kami beli bahan, apa lagi barang-barang naik, adanya koperasi kami bisa meminjam modal dan kami bayar perbulan ke koperasi, ini sangat membantu kami" Lebih lanjut beliau menjelaskan dampak yang dirasakan masyarakat sangat besar, masyarakat yang kekurangan modal usaha bisa meminjam dana di koperasi dan akan dibayar dengan cara mengangsur perbulan, pihak koperasi sangat membuka kerjasama dengan masyarakat yang ingin meminjamkan dana ke koperasi, bagi pengurus koperasi salah satu metode yang dapat mengatasi kemiskinan yaitu dengan meminjamkan modal usahakan bagi masyarakat, disamping membantu masyarakat juga untuk memandirikan masyarakat dalam meningkatkan kesejahteraan, sebagaimana tujuan berdirinya koperasi “

Sangat diperlukan adanya pembinaan yang sifatnya terpadu antara lembaga koperasi di Pemerintahan dengan lembaga lainnya seperti yang ada di USM yaitu dengan PPKU (Pusat Pengembangan Koperasi dan UKM) yang sifatnya bisa membantu pengembangan koperasi yang masih awal berdirinya, dengan cara memberikan pelatihan yang dibutuhkan berkaitan dengan pengelolaan koperasi dan selalu memberikan support untuk terus berkembang dan pendampingan yang sifatnya berkelanjutan.

\section{Simpulan}

Berdasarkan perumusan masalah yang telah diuraikan sebelumnya, maka dapat disimpulkan bahwa

a. Peran perempuan kaitannya dengan pengentasan kemiskinan perlu dikelola dengan cara mendirikan embrio koperasi

b. Pelatihan diberikan untuk bisa memahami mengenai koperasi sehingga mereka punya motivasi untuk mengembangkannya

c. Pendampingan diperlukan secara kontinyu agar setiap hambatan yang dihadapi dalam menjalankan koperasi bisa segera diatasi

d. Yang penting adalah sudah ada kemauan dari kelompok ini untuk mendirikan koperasi terbukti dari adanya kepengurusan untuk mewadahi aspirasi anggota.

e. Pendampingan akan selalu dilakukan sepanjang diperlukan sampai usaha ini sukses dan perempuan yang terlibat didalam koperasi benar-benar bisa merasakan manfaat dari adanya koperasi.

\section{Saran}

a. Perlu adanya kerjasama dengan pemerintah untuk pengembangan koperasi ini sehingga keberadaannya bisa berlanjut dan bermanfaat bagi anggotanya.

b. Hambatan dan kendala perlu diselesaikan secara musyawarah karena pendirian koperasi berlandaskan dari kesamaan keadaan dan kemauan bersama sehingga prinsip dari koperasi terpenuhi yaitu "Dari anggota untuk anggota" 
Dinamika Sosial Budaya, Vol 21, No. 2, Desember 2019, pp 172-181

p-ISSN: 1410-9859\& e-ISSN: 2580-8524

http://journals.usm.ac.id/index.php/jdsb

c. Perlu pembinaan lebih lanjut dengan pihakpihak yang lebih mumpuni kaitannya dengan pengelolaan koperasi

d. Koperasi yang baru didirikan harus bisa dijalankan dengan hati yang tulus, dedikasi yang tinggi, kejujuran dan kepercayaan

\section{DAFTAR PUSTAKA}

Aleria Irma Hatneny, 2017, Koperasi Wanita Dan Pemberdayaan Perempuan Dalam Menumbuhkan Ekonomi Kerakyatan Di Kota Malang, JU-ke, Volume 1, No 2

Atma Ras,2013, Pemberdayaan Masyarakat Sebagai Upaya Pengentasan Kemiskinan, jurnal SOCIUS, vol 14

Creswell, J. W., 2009. Research Design: Qualitative, Quantitative, and Mixed Methods Approaches (3rd Ed.). SAGE.

Haryanto, Sugeng, 2008, Peran Aktif Wanita dalam Peningkatan Rumah Tangga Miskin : Studi Kasus Pada Wanita Pemecah Batu di Pucanganak Kec Tugu, Trenggalek, Jurnal Ekonomi Pembangunan Vol 9, No 2, Des 2008

Hastuti, Dyah Respati, 2008, Model Pemberdayaan Perempuan Miskin Berbasis Sumbedaya Upaya Pengetasan Kemiskinan di Pedesaan, Jurnal Ekonomi Fakultas EKonomi Universitas Negeri Yogyakarta.

Karsidi, R. 2002. Pemberdayaan Masyarakat Petani dan Nelayan Kecil. Semarang.

Lestari, Rahayu Endan, Santoso, Imam; Sulastri, Dwi Rina; 1997, Kontribusi Wanita Dalam Agribisnis Gula Semut di Kab. Blitar, Propinsi Jawa Timur, Jurnal Penelitian Ilmu-Ilmu Sosial Vol.9, No 1 Februari

Neuman, W. L., 2007. Basic of Social Research:Qualitative and Quantitative Approach (2nd Ed.). Pearson Education Inc.

Rahayu, Budiana, MG. 2008. Pembangunan Perekonomian Nasional melalui Pemberdayaan Masyarakat Desa. www.binaswadaya.org/files/Pemberday aan-masyarakat-desa.pdf. [16 November 2009]
Rahayuningsih, Sri dan Agus Murdiyanto, 2015, Upaya Peningkatan Pendapatan Rumah Tangga Miskin Pengrajin Batik Dengan Canting Elektrik (Studi Empirik Pengrajin Batik di Kec Gunung Pati, Semarang), Prosiding Seminar Nasional \& Call for Papers, Fakultas Ekonomika dan Bisnis, Universitas STIKUBANK, Semarang

Rangkuti, Freddy. 2005. Analisis SWOT Teknik Membedah Kasus Bisnis. Jakarta: Gramedia Pustaka Utama

Rusdianti, Endang; Paulus Wardoyo \& Sri Purwantini, 2014, Studi Tentang Keputusan Siswa Melanjutkan Studi di Sekolah Menengah Kejuruan (SMK) Kab.Semarang, Journal \& Proceeding FEB Unsoed, Vol 5, No 1, tahun 2015

Rusdianti, Endang; Paulus Wardoyo \& Sri Purwantini, 2015, Kajian Pengelolaa Dana Koperasi Simpan Pinjam Konvensional di Kota Semarang, Lembaga Penelititan dan Pengabdian Masyarakat Universitas Semarang

Satria, Arif, 2001,Dinamika Modernisasi Perikanan: Formasi Sosial dan Mo -bilitas Nelayan Bandung

Swasono, Sri-Edi (Ed, 1987, Mencari Bentuk, Posisi, dan Realitas Koperasi di dalam Orde Ekonomi Indonesia, Jakarta: UI-Press

Wardoyo, Paulus; Endang Rusdianti, Wyati Saddewisasi, Sri Purwantini dan Najib, 2014, Efektivitas Program Usaha Peningkatan Pendapatan Keluarga Sejahtera di Kab Semarang (Studi Kasus di Kec Ungaran Barat dan Ungaran Timur), Lembaga Penelitian dan Pengabdian Masyakarat, Universitas Semarang

Wardoyo, Paulus, Endang Rusdianti dan Sri Purwantini, 2014, Pengaruh Orientasi Kewirausahaan Terhadap Strategi Usaha dan Kinerja Bisnis UMKM di Desa Ujungujung, Kec Pabelan, Kab Semarang, Journal \& Proceeding FEB Unsoed, Vol 5, No 1, tahun 2015

Wibowo, B Junianto, 2002, Profil Wanita Pedagang Kecil di Tinjau dari Aspek Ekonomi (Studi Kasus pada Tiga Pasar 
Dinamika Sosial Budaya, Vol 21, No. 2, Desember 2019, pp 172-181

p-ISSN: 1410-9859\& e-ISSN: 2580-8524

http://journals.usm.ac.id/index.php/jdsb

Tradisional di Kota Semarang, yaitu Psr Gayam, Psr Damar dan Psr Mangkang) Seri Kajian Ilmiah Vol 11 No 3

Yuniarti, Sari dan Haryanto, Sugeng, 2005, Pekerja Wanita Pada Industri Rumah Tangga Sandang an KOnstribusinya Terhadap Pendapatan Rumah Tangga di Kecamatan Sukun Malan, Jurnal Penelitian Universitas Merdeka Malan, Vo XVII Nomo2 tahun 2005

Yulianto, Trimo, 2005, Fenomena ProgramProgram Pengentasan Kemiskinan di Kabupaten Klaten (Studi Kasus Desa Jotangan Kecamatan Bayat), sebagai Tesis Program Studi Magister Teknik Pembangunan Wilayah dan Kota, Semarang: Universitas Diponegoro 